\title{
Knee Osteoarthritis Research in India: A Scientometric Assessment of Publications Output During 2008-17
}

\author{
Gupta BM${ }^{1}$ and Ritu Gupta ${ }^{2 *}$ \\ ${ }^{1}$ Formely Technology and Development Studies, India \\ ${ }^{2}$ Formely Sri venkateshwara University, India
}

Submission: March 26, 2018; Published: May 11, 2018

*Corresponding author: Ritu Gupta, Formely Sri venkateshwara University, 1K/A Arjun Nagar, Safdarjang Enclave, New Delhi 110029, India, Email: ritu7648@gmail.com

\begin{abstract}
The paper examines 432 Indian publications on knee osteoarthritis research, as covered in Scopus database during 2007-16, registering an annual average growth rate of $6.86 \%$, global publication share of $24.05 \%$ and qualitative citation impact averaged to 6.89 citations per paper and international collaborative publication share of $24.07 \%$. Medicine, among subjects, accounted for the highest publications share (78.47\%), followed by followed by pharmacology, toxicology \& pharmaceutics (14.58\%) biochemistry, genetics \& molecular biology (14.12\%) and immunology \& microbiology (2.55\%) during 2008-17. The top 15 most productive organizations and authors in knee osteoarthritis together contributed $40.51 \%$ and $33.10 \%$ respectively as their share of global publication output and $71.67 \%$ and $70.77 \%$ respectively as their share of global citation output during 2007-16. Among the total journal output of 420 papers, the top 15 journals contributed $36.90 \%$ share to the Indian journal output in knee osteoarthritis during 2007-16. Journal of Arthoplasty was the most productive journal with 35 papers.
\end{abstract}

Keywords: Allogenic bone graft; Fracture healing; Non union; Difficult fracture

\section{Introduction}

Knee is the largest joint in the body and it is located where your thigh bone (femur) and your shin bone (tibia) meet. It allows the bones to move freely but within limits and is enough to take our weight and it locks into position to help us stand upright. It has to act also as a hinge to help us in walking and it withstands extreme stresses, twists and turns, whenever we run or play sports. During knee osteoarthritis, knee surfaces become damaged and it doesn't move as well as it should do, resulting in following:

i. The cartilage becomes rough and thin-over the main surface of your knee joint and in the cartilage underneath your kneecap,

ii. The bone underneath the cartilage reacts by growing thicker and becoming broader,

iii. All the tissues in your joint become more active than normal, as if your body is trying to repair the damage,

iv. The bone at the edge of your joint grows outwards, forming bony spurs called osteophytes,

v. The synovium may swell and produce extra fluid, causing the joint to swell - this is called an effusion or sometimes water on the knee and vi. The capsule and ligaments slowly thicken and contract. These changes in and around your joint are partly the result of the inflammatory process and partly an attempt by your body to repair the damage. In many cases your body's repairs are quite successful and the changes inside your joint won't cause much pain or, if there is pain, it'll be mild and may come and go. However, in other cases the repair doesn't work as well and your knee is damaged. This leads to instability and more weight being put onto other parts of the joint [1].

Almost everyone will eventually develop some degree of osteoarthritis. However, several factors increase the risk of developing significant arthritis at an earlier age: Weight, heredity, gender, repetitive stress injuries, athletics and other illnesses [2]. The most prevalent form of arthritis in India, osteoarthritis affects over 15 million adults every year. In the last few decades, Indians in the age-group of 30 to 50 years are falling prey to osteoarthritis and it continues to have serious impact on the lives of elderly people., Come 2025 and India is likely to notice an endemic of osteoarthritis with about 80 percent of the 65 and above population in the country suffering with wear and tear of joints. Forty percent of these people are likely to suffer from severe osteoarthritis, which will disable them from daily activities [3]. The reason behind the onset of this endemic is said 
to be increasing longevity of Indians. By 2020, the number of 65 and above population in India is likely to be about 177 million, whereas India had 100 million people in this age group in 2010.

\section{Literature Review}

Few bibliometric studies related to knee osteoarthritis were published in the past. Among such studies, Ajuied, Back, Smith, Davies, Wong \& Earnshaw [4] studied knee arthroplasty and soft tissue surgery publications (7500 from 1995 to 2010), with regard to their geographical authorship, institutional funding and number of authors. Eom, Bamne, Chowdhry, Chae \& Kim [5] studied quantity and quality of research in total knee arthroplasty (TKA) from Asian countries, in terms of total number of publications and citations, with countryspecific contribution. Kumar, Gupta \& Goel [6] examined 792 Indian osteoarthritis research publications indexed in Scopus database during 2007-16. The study focused on growth rate, citation impact, international collaboration, broad subject-wise distribution, productivity of leading organizations, authors, journals and bibliographic characteristics of high cited papers.

\section{Objectives}

The objectives of the present study are to study the performance of Indian knee osteoarthritis research output during 2008-17, using on publications data covered in Scopus database. The study, in particular focuses on growth date of Indian research output in knee osteoporosis research, its global share and citation impact; its international collaboration share and significant foreign partner countries; its distribution by broad subject areas, its publication productivity and citation impact by top 15 Indian most productive organizations and authors and its principal medium of communication.

\section{Methodology}

The knee osteoarthritis research publications landscape from 2008 through 2017 was identified using the Scopus database (http://www.scopus.com). An keyword search was used to identify publications that contained the terms "knee osteoporosis" in the "Article title tag" or " keyword tags" and restricting it to the period 2008-17 in "date range tag" was used for searching the global and Indian publication data and this become the main search string. The search has resulted into 21164 global and 432 Indian publications on knee osteoarthritis research during 2008-17. When the main search string for India publications, using various analytical provisions in Scopus database, was restricted to "subject area tag", "country tag", "source title tag", "journal title name" and "affiliation tag", we were able to get information on distribution of publications by subject, collaborating countries, author-wise, organization-wise and journal-wise, etc. For citation data, citations to publications were also collected from date of publication till 23 February 2018. (KEY (knee osteoarthritis) OR TITLE (knee osteoarthritis)) AND PUBYEAR > 2007 AND PUBYEAR < 2018 ( KEY ( knee AND osteoarthritis ) OR TITLE ( knee AND osteoarthritis ) ) AND PUBYEAR > 2007 AND PUBYEAR < 2018 AND ( LIMIT-TO ( AFFILCOUNTRY, "India “) ).

\section{Analysis}

Table 1: India Research Output in Knee Osteoarthritis Research during 2008-17.

\begin{tabular}{|c|c|c|c|c|c|c|c|}
\hline \multirow{2}{*}{$\begin{array}{c}\text { Publication } \\
\text { Year }\end{array}$} & \multirow{2}{*}{$\begin{array}{c}\text { World } \\
\text { TP }\end{array}$} & \multicolumn{6}{|c|}{ India } \\
\hline & & TP & TC & CPP & $\% \mathrm{TP}$ & ICP & $\%$ ICP \\
\hline 2008 & 1481 & 13 & 371 & 28.54 & 0.88 & 5 & 38.46 \\
\hline 2009 & 1534 & 20 & 222 & 11.10 & 1.30 & 1 & 5.00 \\
\hline 2010 & 1627 & 19 & 279 & 14.68 & 1.17 & 5 & 26.32 \\
\hline 2011 & 1754 & 33 & 469 & 14.21 & 1.88 & 4 & 12.12 \\
\hline 2012 & 2051 & 33 & 389 & 11.79 & 1.61 & 5 & 15.15 \\
\hline 2013 & 2278 & 62 & 619 & 9.98 & 2.72 & 13 & 20.97 \\
\hline 2014 & 2500 & 59 & 359 & 6.08 & 2.36 & 13 & 22.03 \\
\hline 2015 & 2582 & 58 & 113 & 1.95 & 2.25 & 16 & 27.59 \\
\hline 2016 & 2692 & 71 & 132 & 1.86 & 2.64 & 23 & 32.39 \\
\hline 2017 & 2665 & 64 & 23 & 0.36 & 2.40 & 19 & 29.69 \\
\hline 2008-12 & 8447 & 118 & 1730 & 14.66 & 1.40 & 20 & 16.95 \\
\hline 2013-17 & 12717 & 314 & 1246 & 3.97 & 2.47 & 84 & 26.75 \\
\hline 2008-17 & 21164 & 432 & 2976 & 6.89 & 2.04 & 104 & 24.07 \\
\hline
\end{tabular}

TP: Total Papers; TC: Total Citations; CPP: Citations Per Paper.

The total research output of India in knee osteoarthritis research consisted of cumulated to 432 publications in 10 years during 2008-17, using a Scopus database. The annual output of global and India in osteoarthritis research increased from 1481 and 13 in the year 2008 to 2665 and 64 publications in the year 2017, registering $6.86 \%$ and $24.05 \%$ growth per annum. The cumulative global and Indian output in knee osteoarthritis research computing in 5 years increased from 8447 and 118 during 2008-12 to 12717 and 314 during 2013-17, registering growth rate of $50.55 \%$ and $166.10 \%$. India is ranked at $17^{\text {th }}$ 


\section{Orthopedics and Rheumatology Open Access Journal (OROAJ)}

position in global output and its global publication share in knee osteoarthritis research was $2.04 \%$ during 2008-17, which increased from $1.40 \%$ to $2.47 \%$ from $2008-12$ to $2013-17$. Of the total global publications output, 78.70\% (340) was published as articles, $7.41 \%$ (32) as reviews, $7.18 \%$ (31) as letters, $4.17 \%$ (18) as conference papers, $1.39 \%$ (6) as notes and 1.16 $\%$ (5) as editorials. The citation impact of Indian publications on knee osteoarthritis research averaged to 6.89 citations per publication (CPP) during 2007-16; five-yearly impact averaged to $14.66 \mathrm{CPP}$ for the period 2008-12 which declined to $3.97 \mathrm{CPP}$ in the succeeding five-year 2013-17 (Table 1).

\section{International Collaboration}

India's share of internationally collaborative papers (ICP) (104) in knee osteoarthritis research was $24.07 \%$ during 2008-
17, which increased from $16.95 \%$ to $26.75 \%$ from $2008-12$ to 2013-17. These 104 international collaborative papers together have received 938 citations, registering citation impact per paper of 9.02. Among the 37 countries contributing to internationally collaborative papers, USA topped the list with $25.96 \%$ share, followed by Saudi Arabia and South Korea (17.31\% each), U.K. (13.46\%), Canada and Germany (6.73\% each), Italy (5.77\%), Australia (4.81\%), Malaysia and Netherland (3.85\% each) during 2008-17. India's international collaborative publications share increased by $21.4 \%$ in Saudi Arabia, $16.7 \%$ in U.K., $8.3 \%$ in Canada, $7.1 \%$ in Italy, $6.0 \%$ in Australia, $2.9 \%$ in South Korea and $1.2 \%$ in USA, as against decrease by $4.1 \%$ in Germany and 1.4\% each in Netherland and Malaysia from 2008-12 to 2013-17 (Table 2).

Table 2: Share of Leading Foreign Countries in India's Collaborative. Research Output in Knee Osteoarthritis Research during 2008-17.

\begin{tabular}{|c|c|c|c|c|c|c|c|}
\hline \multirow{2}{*}{ S. No } & \multirow{2}{*}{$\begin{array}{c}\text { Collaborative } \\
\text { Country }\end{array}$} & \multicolumn{3}{|c|}{ Number of Papers } & \multicolumn{3}{c|}{ Share of Papers } \\
\cline { 3 - 8 } & USA & $\mathbf{2 0 0 8 - 1 2}$ & $\mathbf{2 0 1 3 - 1 7}$ & $\mathbf{2 0 0 8 - 1 7}$ & $\mathbf{2 0 0 8 - 1 2}$ & $\mathbf{2 0 1 3 - 1 7}$ & $\mathbf{2 0 0 8 - 1 7}$ \\
\hline 1 & 5 & 22 & 27 & 25.00 & 26.19 & 25.96 \\
\hline 2 & Saudi Arabia & 0 & 18 & 18 & 0.00 & 21.43 & 17.31 \\
\hline 3 & South Korea & 3 & 15 & 18 & 15.00 & 17.86 & 17.31 \\
\hline 4 & U.K. & 0 & 14 & 14 & 0.00 & 16.67 & 13.46 \\
\hline 5 & Canada & 0 & 7 & 7 & 0.00 & 8.33 & 6.73 \\
\hline 6 & Germany & 2 & 5 & 7 & 10.00 & 5.95 & 7.14 \\
\hline 7 & Italy & 0 & 6 & 6 & 0.00 & 5.73 \\
\hline 8 & Australia & 0 & 5 & 5 & 0.00 & 5.95 & 4.81 \\
\hline 9 & Malaysia & 1 & 3 & 4 & 5.00 & 3.57 & 3.85 \\
\hline 10 & Netherland & 1 & 3 & 4 & 5.00 & 3.57 & 3.85 \\
\hline & Indian Total & 20 & 84 & 104 & & & \\
\hline
\end{tabular}

Top 10 Most Productive Countries in Knee Osteoarthritis Research

Table 3: Global Publication Share of Top 10 Most Productive Countries in Knee Osteoarthritis Research during 2008-17.

\begin{tabular}{|c|c|c|c|c|c|c|c|}
\hline \multirow{2}{*}{ S.No } & \multirow{2}{*}{$\begin{array}{l}\text { Name of the } \\
\text { Country }\end{array}$} & \multicolumn{3}{|c|}{ Number of Papers } & \multicolumn{3}{|c|}{ Share of Papers } \\
\hline & & 2008-12 & 2013-17 & 2008-17 & 2008-12 & 2013-17 & 2008-17 \\
\hline 1 & USA & 2404 & 3555 & 5959 & 28.46 & 27.95 & 28.16 \\
\hline 2 & U.K. & 898 & 1153 & 2051 & 10.63 & 9.07 & 9.69 \\
\hline 3 & China & 388 & 1207 & 1595 & 4.59 & 9.49 & 7.54 \\
\hline 4 & Germany & 637 & 802 & 1439 & 7.54 & 6.31 & 6.80 \\
\hline 5 & Australia & 482 & 845 & 1327 & 5.71 & 6.64 & 6.27 \\
\hline 6 & Canada & 552 & 731 & 1283 & 6.53 & 5.75 & 6.06 \\
\hline 7 & Japan & 463 & 742 & 1205 & 5.48 & 5.83 & 5.69 \\
\hline 8 & Netherland & 350 & 562 & 912 & 4.14 & 4.42 & 4.31 \\
\hline 9 & France & 382 & 506 & 888 & 4.52 & 3.98 & 4.20 \\
\hline \multirow[t]{4}{*}{10} & South Korea & 282 & 509 & 791 & 3.34 & 4.00 & 3.74 \\
\hline & $\begin{array}{l}\text { Total of } 10 \\
\text { countries }\end{array}$ & 6838 & 10612 & 17450 & 80.95 & 83.45 & 82.45 \\
\hline & World & 8447 & 12717 & 21164 & & & \\
\hline & $\begin{array}{l}\text { Share of } 10 \\
\text { Countries in } \\
\text { World Total }\end{array}$ & 80.95 & 83.45 & 82.45 & & & \\
\hline
\end{tabular}




\section{Orthopedics and Rheumatology Open Access Journal (OROAJ)}

116 countries participated in global knee osteoarthritis research during 2008-17. Amongst these 116 countries, 53 countries contributed 1-10 papers each, 24 countries 11-50 papers each, 10 countries 51-100 papers each, 15 countries 101500 papers each, 7 countries 501-1000 papers each, 5 countries 1001-2000 papers each and 2 countries 2051-5959 papers each during 2008-17. Table 2 presents the knee osteoarthritis output of top 10 most productive countries during 2008-17. The publication share of the 10 most productive countries in knee osteoarthritis together contributed $82.45 \%$ global share during $2008-17$, showing increase from $80.95 \%$ to $84.45 \%$ from 2008 12 to 2013-17. The global publication share of individual 10 countries varied from $3.74 \%$ to $28.16 \%$ during $2008-17$, with highest publication share (28.16\%) coming from USA, followed by U.K. (9.69\%), China (7.54\%), Germany, Australia and Canada (from $6.06 \%$ to $6.80 \%$ ), Japan (5.69\%), Netherlands and France (4.31\% and 4.20\%) and South Korea (3.74\%) during 2008-17. The following countries showed increase in global share: $4.90 \%$ in China, $0.94 \%$ in Australia, $0.66 \%$ in South Korea, 0.35\% in Japan and $0.28 \%$ in Netherlands, as against decrease in : $1.56 \%$ in U.K., $1.23 \%$ in Germany, $0.79 \%$ in Canada, $0.54 \%$ in France and $0.51 \%$ in USA from $2008-12$ to $2013-16$. Of the 10 countries, six have scored relative citation index more than the average of 1.23: Netherlands (1.64), Canada (1.49), U.K (1.47), USA (1.37), Australia (1.35), France (1.32) and Germany (1.27) during 200817 (Table 3).

\section{Subject-Wise Distribution of Research Output}

Table 4: Subject-Wise Breakup of Indian Publications in Knee Osteoarthritis Research during 2008-17.

\begin{tabular}{|c|c|c|c|c|c|c|c|c|c|}
\hline \multirow{2}{*}{ S.No } & Subject* & \multicolumn{2}{|c|}{ Number of Papers (TP) } & \multicolumn{2}{c|}{ Activity Index } & TC & CPP & \%TP \\
\cline { 2 - 11 } & Medicine & $\mathbf{2 0 0 8 - 1 2}$ & $\mathbf{2 0 1 3 - 1 7}$ & $\mathbf{2 0 0 8 - 1 7}$ & $\mathbf{2 0 0 8 - 1 2}$ & $\mathbf{2 0 1 3 - 1 7}$ & $\mathbf{2 0 0 8 - 1 7}$ & $\mathbf{2 0 0 8 - 1 7}$ & $\mathbf{2 0 0 8 - 1 7}$ \\
\hline 1 & 99 & 240 & 339 & 106.91 & 97.40 & 2668 & 7.87 & 78.47 \\
\hline 2 & $\begin{array}{c}\text { Pharmacology, Toxicology \& } \\
\text { Pharmaceutics }\end{array}$ & 20 & 43 & 63 & 116.22 & 93.90 & 250 & 3.97 & 14.58 \\
\hline 3 & $\begin{array}{c}\text { Biochemistry, Genetics \& Molecular } \\
\text { Biology }\end{array}$ & 9 & 52 & 61 & 54.02 & 117.28 & 229 & 3.75 & 14.12 \\
\hline 4 & Immunology \& Microbiology & 2 & 9 & 11 & 66.56 & 112.57 & 193 & 17.55 & 2.55 \\
\hline & Total Indian Output & 118 & 314 & 432 & & & & & \\
\hline
\end{tabular}

There is overlapping of literature covered under various subjects.

TP: Total Papers; TC: Total Citations; CPP: Citations Per Paper.

The Indian knee osteoarthritis research output published during 2008-17 is distributed across four sub-fields (as identified in Scopus database classification), with medicine accounting for the highest publications share (78.47\%), followed by pharmacology, toxicology \& pharmaceutics (14.58\%) biochemistry, genetics \& molecular biology (14.12\%) and immunology \& microbiology (2.55\%) during 2008-17. The activity index, which computes change in research activity in a discipline over time 2008-12 to 2013-17 (world average activity index of a given subject is taken as 100), witnessed increase in biochemistry, genetics \& molecular biology (from 54.02 to 117.28 ) and immunology \& microbiology (from 66.56 to 112.57), as against decline of research activity in medicine (from 106.91 to 97.40) and pharmacology, toxicology \& pharmaceutics (from 116.22 to 93.90), from 2008-12 to 2013-17. Immunology \& microbiology among three subjects registered the highest citation impact per paper (17.55), followed by medicine (7.87), pharmacology, toxicology \& pharmaceutics (3.97) and biochemistry, genetics \& molecular biology (3.75) and during 2008-17 (Table 4).

\section{Significant Keywords}

A large number of significant keywords have been identified from the literature, which throw light on the research trends in knee osteoarthritis. These keywords are listed in Table 5 in the decreasing order of the frequency of occurrence during 2008-17.

Table 5: List of Significant Keywords Appearing in Indian Knee Osteoarthritis Literature during 2008-17

\begin{tabular}{|c|c|c|c|c|c|}
\hline S.No & Name of Keyword & Frequency & S.No & Name of Keyword & Frequency \\
\hline 1 & Knee Osteoarthritis & 324 & 16 & Knee Replacement & 37 \\
\hline 2 & Osteoarthritis & 201 & 17 & Knee Prosthesis & 30 \\
\hline 3 & Knee & 105 & 18 & Rheumatoid Arthritis & 29 \\
\hline 4 & Knee Joint & 89 & 20 & NMR Imaging & 26 \\
\hline 5 & $\begin{array}{c}\text { Arthoplasty } \\
\text { Replacement, Knee }\end{array}$ & 81 & 21 & Hyaluronic Acid & 28 \\
\hline 7 & Knee Pain & 79 & 22 & Placebo & 26 \\
\hline
\end{tabular}




\section{Orthopedics and Rheumatology Open Access Journal (OROAJ)}

\begin{tabular}{|c|c|c|c|c|c|}
\hline 8 & $\begin{array}{c}\text { Total Knee } \\
\text { Replacement }\end{array}$ & 62 & 23 & Pathophysiology & 22 \\
\hline 9 & Drug Efficacy & 64 & 24 & Histopathology & 21 \\
\hline 10 & Knee Radiography & 49 & 25 & Osteotomy & 19 \\
\hline 11 & Drug Safety & 43 & 26 & Weight Bearing & 17 \\
\hline 12 & Scoring System & 43 & 28 & Cartilage & Anti-inflammatory \\
\hline 13 & Knee Arthoplasty & 42 & 20 & Obesity & 19 \\
\hline 14 & Pain & 42 & & & \\
\hline 15 & Knee Function & 39 & & \\
\hline
\end{tabular}

Profile of Top 10 Most Productive Indian Organizations

Table 6: Scientometric Profile of Top 15 Most Productive Organizations.

\begin{tabular}{|c|c|c|c|c|c|c|c|c|}
\hline S.No & Name of the Organization & TP & TC & CPP & HI & ICP & $\% \mathrm{ICP}$ & RCI \\
\hline 1 & All India Institute of Medical Sciences, New Delhi & 25 & 165 & 6.60 & 6 & 5 & 20.00 & 0.96 \\
\hline 2 & Postgraduate Institute of Medical Education \& Research, Chandigarh & 22 & 354 & 16.09 & 7 & 2 & 9.09 & 2.34 \\
\hline 3 & Breach Candy Hospital, Bombay & 21 & 502 & 23.90 & 11 & 3 & 14.29 & 3.47 \\
\hline 4 & Bharati Vidyapeeth University, Pune & 12 & 67 & 5.58 & 4 & 0 & 0.00 & 0.81 \\
\hline 5 & CSM Medical University, Lucknow & 12 & 137 & 11.42 & 5 & 2 & 16.67 & 1.66 \\
\hline 6 & Dr D Y Patil College of Physiotherapy, Pune & 12 & 56 & 4.67 & 4 & 11 & 91.67 & 0.68 \\
\hline 7 & Centre for Rheumatic Diseases, Pune & 10 & 263 & 26.30 & 8 & 4 & 40.00 & 3.82 \\
\hline 8 & Indraprastha Apollo Hospital, Delhi & 10 & 20 & 2.00 & 2 & 1 & 10.00 & 0.29 \\
\hline 9 & Lilavati Hospital \& Research Centre, Bombay & 10 & 187 & 18.70 & 4 & 0 & 0.00 & 2.71 \\
\hline 10 & Manipal Academy of Higher Education & 10 & 187 & 18.70 & 3 & 0 & 0.00 & 2.71 \\
\hline 11 & Sanjay Gandhi Postgraduate Institute of Medical Sciences, Lucknow & 7 & 86 & 12.29 & 5 & 0 & 0.00 & 1.78 \\
\hline 12 & University of Lucknow & 6 & 40 & 6.67 & 2 & 0 & 0.00 & 0.97 \\
\hline 13 & Institute of Post Graduate Medical Education \& Research, Kolkata & 6 & 38 & 6.33 & 2 & 0 & 0.00 & 0.92 \\
\hline 14 & Seth G.S. Medical College \& KEM Hospital, Bombay & 6 & 4 & 0.67 & 1 & 0 & 0.00 & 0.10 \\
\hline \multirow[t]{4}{*}{15} & Poona College of Pharmacy & 6 & 27 & 4.50 & 3 & 0 & 0.00 & 0.65 \\
\hline & Total of 15 organizations & 175 & 2133 & 12.19 & 4.47 & 28 & 16.00 & 1.77 \\
\hline & Total of India & 432 & 2976 & 6.89 & & & & \\
\hline & Share of top 15 organizations in India total output & 40.51 & 71.67 & & & & & \\
\hline
\end{tabular}

TP: Total Papers; TC: Total Citations; CPP: Citations Per Paper; HI: h-index; ICP: International Collaborative Papers; RCl: Relative Citation Index.

280 organizations participated in Indian knee osteoarthritis research, of which 271 organizations contributed 1-5 papers each, 11 organizations 6-10 papers each, 5 organizations 11-20 papers and 3 organizations 21-30 papers each. The productivity of 15 most productive organizations In Indian knee osteoarthritis research varied from 6 to 25 publications and together they contributed $40.51 \%$ (175) publication share and $71.67 \%$ (2133) citation share to its cumulative publications output during 2008-17. The scientometric profile of these 15 organizations is presented in Table 6.

i. Six of these organizations registered publications output greater than the group average of 11.67: All India Institute of Medical Sciences, New Delhi (25 papers), Postgraduate Institute of Medical Education \& Research, Chandigarh (22 papers), Breach Candy Hospital, Bombay
(21 papers), Bharati Vidyapeeth University, Pune, CSM Medical University, Lucknow and Dr D Y Patil College of Physiotherapy, Pune (12 papers each) during 2008-17;

ii. Six organizations registered impact above the group average of 12.19 citations per publication during 2007-16: Centre for Rheumatic Diseases, Pune (26.3), Breach Candy Hospital, Bombay (23.9), Lilavati Hospital \& Research Centre, Bombay (18.7), Manipal Academy of Higher Education (18.7), Postgraduate Institute of Medical Education \& Research, Chandigarh (16.09), and Sanjay Gandhi Postgraduate Institute of Medical Sciences, Lucknow (12.29) during 200817 ;

iii. Four organizations contributed international collaborative publications share above the group average of 
16.0\%: Dr D Y Patil College of Physiotherapy, Pune $91.67 \% 0$, Centre for Rheumatic Diseases, Pune(40.0\%), All India Institute of Medical Sciences, New Delhi (20.0\%) and CSM Medical University, Lucknow (16.67\%) during 2008-17;

iv. Six organizations registered the relative citation index above the group average (1.77) of all organizations: Centre for Rheumatic Diseases, Pune (3.82), Breach Candy Hospital, Bombay (3.47), Lilavati Hospital \& Research Centre, Bombay (2.71), Manipal Academy of Higher Education (2.71), Postgraduate Institute of Medical Education \& Research, Chandigarh (2.34) and Sanjay Gandhi Postgraduate Institute of Medical Sciences, Lucknow (1.78) during 2008-17.

\section{Profile of Top 15 Most Productive authors}

Table 7: Scientometric Profile of Top 15 Most Productive Authors in Knee Osteoarthritis Research in India during 2008-17.

\begin{tabular}{|c|c|c|c|c|c|c|c|c|c|}
\hline S.No & $\begin{array}{l}\text { Name of the } \\
\text { Author }\end{array}$ & Affiliation of the Author & TP & TC & CPP & HI & ICP & \%ICP & RCI \\
\hline 1 & G.M. Shetty & Breach Candy Hospital, Bombay & 19 & 320 & 16.84 & 10 & 5 & 26.32 & 2.44 \\
\hline 2 & A.Chopra & Centre for Rheumatic Diseases, Pune & 17 & 295 & 17.35 & 8 & 5 & 29.41 & 2.52 \\
\hline 3 & A.Mullaji & Breach Candy Hospital, Bombay & 17 & 287 & 16.88 & 10 & 1 & 5.88 & 2.45 \\
\hline 4 & R.N.Maniar & Lilavati Hospital \& Research Centre, Bombay & 10 & 187 & 18.70 & 4 & 0 & 0.00 & 2.71 \\
\hline 5 & M.S.Dhillon & $\begin{array}{l}\text { Postgraduate Institute of Medical Education \& } \\
\text { Research, Chandigarh }\end{array}$ & 10 & 242 & 24.20 & 3 & 2 & 20.00 & 3.51 \\
\hline 6 & P. Sancheti & $\begin{array}{c}\text { Sancheti Institute of Orthopaedic Rehabilitation, } \\
\text { Pune }\end{array}$ & 10 & 27 & 2.70 & 2 & 9 & 90.00 & 0.39 \\
\hline 7 & V. Kumar & All India Institute of Medical Sciences, New Delhi & 7 & 29 & 4.14 & 4 & 3 & 42.86 & 0.60 \\
\hline 8 & A. Singh & King George's Medical University, Lucknow & 7 & 70 & 10.00 & 4 & 0 & 0.00 & 1.45 \\
\hline 9 & T. Singhi & Breach Candy Hospital, Bombay & 7 & 186 & 26.57 & 4 & 0 & 0.00 & 3.86 \\
\hline 10 & R.N.Srivastava & King George's Medical University, Lucknow & 7 & 76 & 10.86 & 5 & 1 & 14.29 & 1.58 \\
\hline 11 & R. Vaishya & Indraprastha Apollo Hospital, Delhi & 7 & 5 & 0.71 & 1 & 0 & 0.00 & 0.10 \\
\hline 12 & V.Vijay & Indraprastha Apollo Hospital, Delhi & 7 & 5 & 0.71 & 1 & 0 & 0.00 & 0.10 \\
\hline 13 & A. Mishra & King George's Medical University, Lucknow & 6 & 75 & 12.50 & 5 & 1 & 16.67 & 1.81 \\
\hline 14 & S.Patel & $\begin{array}{l}\text { Postgraduate Institute of Medical Education \& } \\
\text { Research, Chandigarh }\end{array}$ & 6 & 227 & 37.83 & 2 & 0 & 0.00 & 5.49 \\
\hline \multirow[t]{5}{*}{15} & D.Sanghi & King George's Medical University, Lucknow & 6 & 75 & 12.50 & 5 & 1 & 16.67 & 1.81 \\
\hline & Total of 15 authors & & & & & & & & \\
\hline & 143 & 2106 & 14.73 & 4.53 & 28 & 19.58 & 2.14 & & \\
\hline & Total of India & & 432 & 2976 & 6.89 & & & & \\
\hline & $\begin{array}{l}\text { Share of top } 15 \\
\text { authors in Indian } \\
\text { total output }\end{array}$ & & 33.10 & 70.77 & & & & & \\
\hline
\end{tabular}

TP: Total Papers; TC: Total Citations; CPP: Citations per Paper; HI: h-index; ICP: International Collaborative Papers; RCI: Relative Citation Index.

371 authors participated in Indian knee osteoarthritis research, of which 351 authors contributed 1-5 papers each, 17 authors 6-10 papers each and 3 authors 11-20 papers each. The productivity of 15 most productive authors in Indian knee osteoarthritis research varied from 6 to 19 publications. Together they contributed $33.1 \%$ (143) global publication share and $70.77 \%$ (2106) citation share during 2008-17. The scientometric profile of these 15 authors is presented in Table 7.

a. Six authors registered publications output above the group average of 9.53: G.M. Shetty (19 papers), A. Chopra and A. Mullaji (17 papers each), R.N. Maniar, M.S. Dhillon and P.Sancheti (10 papers each) during 2008-17; b. Seven authors registered impact above the group average of 14.73 citations per publication: S. Patel (37.83), T Singhi (26.57), MS Dhillon (24.2), RN Maniar (18.7), A Chopra(17.35), A Mullaji (16.88) and GM Shetty (16.84) during 2008-17;

c. Five authors contributed international collaborative publications share above the group average of $19.58 \%$ of all authors: P Sancheti (90.0\%), V Kumar (42.86\%), A Chopra (29.41\%), G.M. Shetty (26.32\%) and MS Dhillon (20.0\%) during 2008-17;

d. Seven authors registered the relative citation index above the group average (2.14) of all authors: S Patel (5.49), 


\section{Orthopedics and Rheumatology Open Access Journal (OROAJ)}

T. Singhi(3.86), MS Dhillon (3.51), RN Maniar (2.71), A Chopra (2.52), A Mullaji (2.45) and G.M. Shetty (2.44) during 2008-17.

\section{Medium of Communication}

210 journals participated in Indian knee osteoarthritis research, of which 195 journals contributed 1-5 papers each, 12 journals 6-10 papers each and 3 journals 21-35 papers each. Of the total Indian publications output in knee osteoarthritis research, 97.22\% (420) appeared in journals. The top 15 most productive journals accounted for 5 to 35 papers each in knee osteoarthritis research and together accounted for $36.90 \%$ share (155 papers) of total journal publication output during 2008-17. The publication share of these top 15 most productive journals decreased from $41.03 \%$ to $35.31 \%$ between $2008-12$ and 2013 17. The top most productive journal (with 35 papers) was Journal of Arthoplasty, followed by Osteoporosis International (26 papers), Indian Journal of Orthopaedics (10 papers), Indian Journal of Rheumatology, International Journal of Rheumatic Diseases and International Orthopaedics (9 papers each), etc. during 2008-17 (Table 8).

Table 8: Top 15 Most Productive Journals in Knee Osteoarthritis Research in India during 2008-17.

\begin{tabular}{|c|c|c|c|c|}
\hline \multirow{2}{*}{ S.No } & \multirow{2}{*}{ Name of the Journal } & \multicolumn{3}{|c|}{ Number of Papers } \\
\hline & & 2008-12 & 2013-17 & 2008-17 \\
\hline 1 & Journal of Arthoplasty & 13 & 22 & 35 \\
\hline 2 & Journal of Clinical \& Diagnostic Research & 1 & 20 & 21 \\
\hline 3 & Indian Journal of Orthopaedics & 2 & 8 & 10 \\
\hline 4 & Indian Journal of Rheumatology & 5 & 4 & 9 \\
\hline 5 & International Journal of Rheumatic Diseases & 5 & 4 & 9 \\
\hline 6 & International Orthopaedics & 3 & 6 & 9 \\
\hline 7 & Knee Surgery Sports Traumatology Arthroscopy & 2 & 7 & 9 \\
\hline 8 & International Journal of Pharma \& Bio Sciences & 3 & 5 & 8 \\
\hline 9 & Knee & 2 & 6 & 8 \\
\hline 10 & Clinical Orthopaedics \& Related Research & 2 & 5 & 7 \\
\hline 11 & Journal of Clinical Orthopaedics \& Trauma & 0 & 7 & 7 \\
\hline 12 & Asian Journal of Pharmaceutical \& Clinical Research & 0 & 6 & 6 \\
\hline 13 & Journal of Ayurveda \& Integrated Medicine & 2 & 4 & 6 \\
\hline 14 & Journal of Indian Medical Association & 5 & 1 & 6 \\
\hline \multirow[t]{4}{*}{15} & Archives of Orthpaedic \& Trauma Surgery & 3 & 2 & 5 \\
\hline & Total of 15 Journals & 48 & 107 & 155 \\
\hline & Total India Journal output & 117 & 303 & 420 \\
\hline & Share of top 15 journals in Indian Journal output & 41.03 & 35.31 & 36.90 \\
\hline
\end{tabular}

\section{Summary \& Conclusion}

India had produced 432 publications on knee osteoarthritis research as indexed in Scopus database in 10 years during 200716 These publications increased from 13 to 64 from the year 2008 to year 2017, registering $24.05 \%$ annual growth. India's global publications share on knee osteoarthritis research was $2.04 \%$ during $2008-17$, which increased from $1.40 \%$ to $2.47 \%$ from 2008-12 to 2013-17. India's citation impact on knee osteoarthritis research averaged to 6.89 citations per publication during 2007-16, which dropped from 14.66 to 3.97 from 200812 to 2013-16. The share of international collaborative papers of India in its research output on knee osteoarthritis research was $24.07 \%$ during $2008-17$, which increased from $16.95 \%$ to $26.75 \%$ from $2008-12$ to $2013-17$. USA contributed the largest share of $25.96 \%$ in international collaborative papers among foreign countries, followed by Saudi Arabia and South Korea (17.31\% each), U.K. (13.46\%), Canada and Germany $(6.73 \%$ each), Italy (5.77\%), Australia (4.81\%), Malaysia and Netherland
(3.85\% each) during 2008-17. India's international collaborative publications share increased in Saudi Arabia, UK, Canada, Italy, Australia, South Korea and USA, as against decrease in Germany, Netherland and Malaysia from 2008-12 to 2013-17.

Medicine, among subjects, accounted for the highest publications share $(78.47 \%)$ in knee osteoarthritis research, followed by pharmacology, toxicology \& pharmaceutics (14.58\%) biochemistry, genetics \& molecular biology (14.12\%) and immunology \& microbiology (2.55\%) during 2008-17. The research activities showed increase in biochemistry, genetics \& molecular biology and immunology \& microbiology, as against decline in medicine and pharmacology, toxicology \& pharmaceutics from 2008-12 to 2013-17. Immunology \& microbiology, among three subjects, registered the highest citation impact per paper (17.55), followed by medicine (7.87), pharmacology, toxicology \& pharmaceutics (3.97) and biochemistry, genetics \& molecular biology (3.75) and during 2008-17. 
The top 15 most productive organizations and authors in knee osteoarthritis together contributed $40.51 \%$ and $33.10 \%$ respectively as their share of global publication output and $71.67 \%$ and $70.77 \%$ respectively as their share of global citation output during 2007-16. The leading most productive Indian organizations contributing to knee osteoarthritis research were All India Institute of Medical Sciences, New Delhi (25 papers), Postgraduate Institute of Medical Education \& Research, Chandigarh (22 papers), Breach Candy Hospital, Bombay (21 papers), Bharati Vidyapeeth University, Pune, CSM Medical University, Lucknow and Dr D Y Patil College of Physiotherapy, Pune (12papers each) during 2008-17.

The leading Indian organizations with comparatively higher citation impact per paper were Centre for Rheumatic Diseases, Pune (26.3), Breach Candy Hospital, Bombay (23.9), Lilavati Hospital \& Research Centre, Bombay (18.7), Manipal Academy of Higher Education (18.7), Postgraduate Institute of Medical Education \& Research, Chandigarh (16.09), and Sanjay Gandhi Postgraduate Institute of Medical Sciences, Lucknow (12.29) during 2008-17. The leading most productive authors contributing to Indian knee osteoarthritis research were GM Shetty (19 papers), A Chopra and A Mullaji (17 papers each), RN Maniar, MS Dhillon and P Sancheti (10 papers each) during 2008-17. The leading Indian authors with comparatively higher citation impact per paper were S Patel (37.83), T Singhi (26.57), MS Dhillon (24.2), RN Maniar (18.7), A. Chopra A Mullaji (16.88) and GM Shetty (16.84) during 2008-17.

Of the 420 journal publications from India on knee osteoarthritis, the top 15 most productive journals accounted for $36.90 \%$ share of total Indian journal publication output during 2008-16, which decreased from $41.03 \%$ to $35.31 \%$ between 2008-12 and 2013-17. Journal of Arthoplasty was the most productive journal with 35 papers, followed by Osteoporosis International (26 papers), Indian Journal of Orthopaedics (10 papers), Indian Journal of Rheumatology, International Journal of Rheumatic Diseases and International Orthopaedics ( 9 papers each), etc. during 2008-17.

Osteoarthritis is a chronic disease; its management should be patient centred and coordinated, with attention to modifiable risk factors and co morbidities. Its focus should be on conservative non-drug treatment, particularly exercise; for overweight or obese patients weight loss is recommended. Management should be evidence based; do not use interventions with high cost and risk that outweigh their benefits. Conclude that clinical practice guidelines needs to be developed in India which should summarize evidence related to the management of knee osteoarthritis and to facilitate uptake of evidence-based knowledge by clinicians.

\section{References}

1. Arthritis Research (2018) How is the knee structured? Arthritis Research, UK.

2. WebMD (2018) Osteoarthritis of the Knee. Degenerative arthritis of the knee. 2005 - 2018. WebMD, Georgia, USA.

3. Zee News (2015) World Arthritis Day: India may have 60 million osteoarthritis cases by 2025. Zee News, India.

4. Ajuied A, Back D, Smith C, Davies AJ, Wong F, et al. (2013) Publication trends in knee surgery: A review of the last 16 Years. J Arthroplasty 28(5): 751-758.

5. Eom SH, Bamne AB, Chowdhry M, Chae IS, Kim TK (2015) Bibliometric analysis of orthopedic literature on total knee arthroplasty in Asian Countries: A 10-year analysis. Knee Surg Relat Res 27(3): 149-155.

6. Kumar, Ashok, Gupta BM, Goel, Sapna (2017) Osteoarthritis research in India: A scientometric assessment of publications output during 2007-16. International Journal of Information Dissemination and Technology 7(3): 157-161.

\section{Your next submission with Juniper Publishers} will reach you the below assets

- Quality Editorial service

- Swift Peer Review

- Reprints availability

- E-prints Service

- Manuscript Podcast for convenient understanding

- Global attainment for your research

- Manuscript accessibility in different formats

( Pdf, E-pub, Full Text, Audio)

- Unceasing customer service

Track the below URL for one-step submission https://juniperpublishers.com/online-submission.php 